\title{
Thematic Approaches to Improve Learning Outcomes Students on A Clean And Healthy Life Theme
}

\section{Agung Heri Wibowo}

SD Negeri Kedungoleng 06

agoenkmoeda@yahoo.com

Article History

accepted 14/11/2020

approved $21 / 11 / 2020$

published 26/11/2020

\begin{abstract}
The purpose of this research is to improve mastery of learning. One of the approaches used in the learning process is a thematic approach. This research uses classroom action research (PTK). The techniques used were data collection techniques using: (1) observation sheets (teachers and students), (2) test questions then analyzed using a percentage formula. The results of this study indicate that (1) the teacher activity in the first cycle with an average score of 2.91 in the sufficient category and in the second cycle the average score of 4.52 was in the very good category (2) the student activity in the first cycle with an average value of 2.86 was in the sufficient category and in the second cycle got an average value of 4.42 in the very good category. While student learning outcomes in the first cycle with a percentage value of $60.3 \%$, and in the second cycle with a percentage value of $86.7 \%$. Based on the results of the research, it can be concluded that with a thematic approach to the theme of Clean and Healthy Living can improve student learning outcomes in the class of SDN Kedungoleng 06.
\end{abstract}

Keywords : Learning outcomes, thematic, PPKn

\begin{abstract}
Abstrak
Tujuan dari penelitian ini untuk meningkatkan penguasaan pembelajaran. Salah satu pendekatan yang digunakan dalam proses pembelajaran adalah pendekatan tematik. Penelitian ini menggunakan penelitian tindakan kelas (PTK). Teknik yang digunakan teknik pengumpulan data menggunakan: (1) Lembar observasi (guru dan siswa), (2) soal tes kemudian dianalisis dengan menggunakan rumus presentase. Hasil penelitian ini menunjukkan bahwa (1) aktivitas guru pada siklus I dengan nilai rata rata yaitu 2,91 dengan kategori cukup dan pada siklus II mendapat nilai rata-rata 4,52 berada pada kategori sangat baik (2) aktivitas siswa pada siklus I dengan nilai rata-rata 2,86 berada pada kategori cukup dan pada siklus II mendapat nilai ratarata 4,42 berada pada kategori sangat baik. Sedangkan hasil belajar siswa pada siklus I dengan persentase nilai $60,3 \%$, dan pada siklus II dengan persentase nilai $86,7 \%$. Berdasakan hasil penelitian, dapat disimpulkan bahwa dengan pendekatan tematik pada Tema Hidup Bersih dan Sehat dapat meningkatkan hasil belajar siswa di kelas SD Negeri Kedungoleng 06.
\end{abstract}

Kata kunci : Hasil belajar, tematik, PPKn

Social, Humanities, and Education Studies (SHEs): Conference Series https://jurnal.uns.ac.id/shes

p-ISSN 2620-9284

e-ISSN 2620-9292 


\section{PENDAHULUAN}

Pendidikan merupakan usaha sadar dan terencana untuk mewujudkan suasana belajar dan proses pembelajaran agar siswa secara aktif mengembangkan potensi dirinya untuk memiliki kekuatan spritual keagamaan, pengendalian diri, kepribadian, kecerdasan, akhlak mulia, serta keterampilan yang diperlukan dirinya dan masyarakat. Menyadari akan pentingnya pendidikan bagi siswa sangat berpengaruh terhadap suatu proses belajar mengajar yang dilaksanakan pada suatu pembelajaran.

Di dalam keseluruhan proses pendidikan disekolah, pembelajaran merupakan aktivitas yang paling utama. Ini berarti bahwa keberhasilan pencapaian dalam pendidikan banyak bergantung pada bagaimana proses pembelajaran dapat berlangsung secara efektif. Pemahaman seorang guru terhadap pengertian pembelajaran akan mempengaruhi cara guru itu mengajar. Oleh karena itu seorang guru harus benar-benar menguasai teknik- teknik dalam mengajar baik itu dari segi penguasaan materi,penguasaan kelas dan penguasaan alat media dalam mengajar agar hasil belajarnya sesuai dengan harapan yang di inginkan.

Pembelajaran tematik atau pembelajaran terpadu adalah suatu konsep pembelajaran yang melibatkan beberapa mata pelajaran untuk memberi pengalaman yang bermakna pada anak. Dalam model ini, guru pun harus mampu membangun bagian keterpaduan melalui satu tema. Pembelajaran tematik sangat menuntun kreativitas guru dalam memilih dan mengembangkan tema pembelajaran. Tema yang di pilih hendaknya diangkat dari lingkungan kehidupan peserta didik, agar pembelajaran menjadi hidup dan tidak kaku. Demikian halnya pembelajaran menjadi ilustrasi dan contoh-contoh yang menarik dalam pembelajaran. Dalam pembelajaran ini guru harus memiliki pemahaman yang luas tentang tema yang akan dipilih dalam mata pelajaran. Sehingga saling berhubungan antara satu dengan yang lainnya. Karena pembelajaran tematik ini merupakan suatu pembelajaran yang menggabungkan antara materi pelajaran dengan pengalaman belajar. Disamping itu guru harus mempunyai kemampuan untuk mengembangkan program pembelajaran yang ditentukan sebelumnya, Peralatan yang di perlukan untuk melaksanakan belajar harus sudah tersedia, baik di lingkungan sekolah maupun di luar.

Secara garis besar, kurikulum 2013 sudah diterapkan mulai tahun 2013. Tetapi pelaksanaanya belum sepenuhnya dilaksanakan. Disekolah SD Negeri Kedungoleng 06 tersebut belum sepenuhnya menerapkan kurikulum 2013 dikarenakan guru- guru disekolah tersebut belum mampu melaksanakan kurikulum 2013 secara baik, mungkin belum terbiasa makanya terasa lebih susah karena penerapan kurikulum 2013 disekolah SD Negeri Kedungoleng 06 baru diterapkan pada tahun 2015. Berbeda dengan sekolah- sekolah lain penerapan kurikulumnya sudah diterapkan pada tahun sebelumnya.

Terkait masalah di atas ini penulis akan mencoba menerapkan pembelajaran tematik pada tema hidup bersih dan sehat.Dengan menerapkan pembelajarantematik pada tema tersebut diharapkan peserta didik dapat memperoleh pengalaman langsung, sehingga dapat menambah kekuatan untuk menerima, menyimpan, dan memproduksi kesan-kesan tentang hal-hal yang dipelajarinya. Pembelajaran tematik Terpadu dapat dikemas dengan tema atau topik.

Menurut Heans, pembelajaran tematik sebagai upaya untuk mengintegraskan perkembangan dan pertumbuhan siswa dan kemampuan pengetahuannya. Sedangkan menurut Hadi Subroto dalam definisi yang lebih professional, bahwa pembelajaran tematik adalah pembelajaran yang diawali dengan suatu pokok bahasan atau tema tertentu yang dikaitkan dengan pokok bahasan lain, konsep tertentu dikaitkan dengan konsep lain, yang dilakukan secara spontan atau direncanakan, baik dalam satu bidang studi atau lebih, dan dengan beragam pengalaman belajar siswa,maka pembelajaran menjadi lebih bermakna 
Sudjana dalam Rahman Johar menjelaskan bahwa pembelajaran pada hakikatnya adalahsuatu proses mengatur dan mengaorganisasikan lingkungan yang ada disekitar anak didik sehingga dapat menumbuhkan dan mendorong anak didik melakukan proses pembelajaran.

Sebagaimana yang dikutip oleh Abuddin Nata bahwa, S.Nasution menjelaskan bahwa mengajar sebagai berikut:

Pertama, mengajar adalah menanamkan pengetahuan kepada peserta didik, dengan tujuan agar pengetahuan tersebut dikuasai dengan sebaik - baiknya oleh peserta didik. Mengajar pada tipe pertama ini dianggap berhasil jika peserta didik menguasai pengetahuan yang ditransferkan oleh guru sebanyak- banyaknya.

Kedua, mengajar adalah menyampaikan kebudayaan kepada peserta didik. Definisi yang kedua ini pada intinya sama dengan defenisi pertama yang menekankan pada guru sebagai pihak yang aktif.

Ketiga mengajar adalah suatu aktivitas mengorganisasi atau mengatur lingkungan sebaik- baiknya dan menghubungkannya dengan peserta didik sehingga terjadi proses belajar.

\section{METODE}

Penelitian ini menggunakan penelitian tindakan kelas (PTK). Dengan pendekatan tematik, pendekatan tematik adalah cara memulai pembelajaran atau seperangkat asumsi mengenai cara belajar mengajar. Menurut sri Anitah menyatakan,bahwa : pembelajaran tematik suatu konsep yang menggunakan pendekatan pembelajaran yang melibatkan konsep konsep secara terkoneksi baik secara inter maupun antar mata pelajaran. Terjalinnya hubungan antar setiap konsep secara terpadu,akan memasilitasi siswa untuk aktif terlibat dalam pembelajaran dan mendorong siswa untuk memahami konsep konsep yang mereka pelajari melalui pengalaman langsung dan menghubungkannya dengan pengalaman pengalaman nyata. Penelitian ini terdiri dari 4 tahapan yaitu : Perencanaan, Tindakan, Pengamatan dan Refleksi. Subjek penelitian ini adalah siswa Kelas 2 SD Negeri Kedungoleng 06. Pembelajaran ini dilaksanakan terdiri dari 2 siklus. Siklus I dilaksanakan pada tanggal 16 November 2020 dan siklus II dilaksanakan pada tanggal 24 November 2020.

\section{HASIL DAN PEMBAHASAN}

Pada penelitian ini dilaksanakan dalam 2 siklus. Tiap siklus terdiri dari 4 tahapan yaitu : 1). Perencanaan, 2). Tindakan, 3). Pengamatan, 4). Refleksi. Proses belajar mengajar pada siklus I, guru memberikan tes untuk mengetahui kemampuan siswa setelah diterapkannya pendekatan Tematik ketuntasan yang diikuti 15 siswa, dengan kriteria ketuntasan minimal yang ditetapkan di SD Negeri Kedungoleng 06 minimal 70. Hasil tes pada siklus I dapat dilihat pada tabr berikut ini.

Tabel 1. Hasil Tes peserta didik Siklus I

\begin{tabular}{lcclc}
\hline Siklus I & \multicolumn{2}{c}{ Pesdik Tuntas } & \multicolumn{2}{c}{ Pesdik Tidak tuntas } \\
\cline { 2 - 5 } & Jmlh & $\%$ & Jmlh & $\%$ \\
\cline { 2 - 5 } & 9 & $60 \%$ & 6 & $46,6 \%$ \\
\hline
\end{tabular}


Berdasarkan KKM yang telah ditetapkan di SD Negeri Kedungoleng 06 bahwa seorang siswa dikatakan tuntas bila memiliki nilai ketuntasan 70 (ketuntasan secara individu), dan suatu kelas dikatakan tuntas apabila $75 \%$ siswa tuntas (secara klasikal). Jadi dapat disimpulkan bahwa ketuntasan belajar siswa secara klasikal untuk siklus I belum tuntas.

Setelah berlangsungnya proses belajar mengajar pada siklus II, guru memberikan tes untuk mengetahui kemampuan siswa setelah diterapkannya pendekatan tematik ketuntasan yang diikuti 15 siswa. Hasil tes belajar pada siklus II Berikut ini hasil peserta didik pada siklus II Pada table berikut:

Tabel 2. Hasil Tes peserta didik Siklus II

\begin{tabular}{llccc}
\hline Siklus II & \multicolumn{2}{c}{ Pesdik Tuntas } & \multicolumn{2}{c}{ Pesdik Tidak tuntas } \\
\cline { 2 - 5 } & Jmlh & $\%$ & Jmlh & $\%$ \\
\hline 13 & $86,7 \%$ & 12 & $13,33 \%$ \\
\hline
\end{tabular}

Berdasarkan tabel di atas, menunjukkan jumlah siswa yang mencapai ketuntasan belajar sebanyak 13 siswa atau (86,7\%) sedangkan 2 siswa atau (13,33\%) belum mencapai ketuntasan belajar. Terlihat jelas bahwa persentase ketuntasan belajar siswa sebesar $(86,7)$ lebih besar dari $75 \%$ untuk mencapi ketuntasan klasikal. Dengan demikian, dapat disimpulkan bahwa ketuntasan hasil belajar siswa melalui pendekatan tematik pada tema hidup bersih dan sehat pada siklus ke II di SD Negeri Kedungoleng 06 sudah mencapai ketuntasan secara klasikal..

\section{SIMPULAN}

Berdasarkan analisis dari hasil penelitian yang dilakukan dikelas II SD Negeri Kedungoleng 06. Aktivitas guru dalam mengelola pembelajaran dengan Pendekatan Tematik untuk Meningkatkan Hasil Belajar Siswa pada Tema Hidup Bersih dan Sehat pada siklus I dengan nilai rata-rata 2,91 berada pada kategori cukup dan meningkat signifikan pada siklus II yaitu dengan nilai rata-rata 4,54 berada pada kategori sangat baik

Aktivitas siswa dalam mengelola pembelajaran dengan Pendekatan Tematik untuk Meningkatkan Hasil Belajar Siswa pada Tema Hidup Bersih dan Sehat pada siklus I dengan nilai rata-rata 2,86 berada pada kategori cukup dan meningkat pada siklus II dengan signifikan yaitu dengan nilai rata-rata 4,42 dengan kategori baik

Hasil belajar siswa dengan Pendekatan Tematik untuk Meningkatkan Hasil Belajar Siswa pada Tema Hidup Bersih dan Sehat siklus I menunjukkan sebanyak 9 siswa yang sudah mencapai ketuntasan individual (70) dengan persentase nilai $60,3 \%$, sedangkan 6 siswa belum mencapai ketuntasan individual dengan presentase $40 \%$ sehingga pada siklus I belum mencapai ketuntasan klasikal (75\%). Pada siklus ke II sebanyak 13 siswa sudah mencapai ketuntasan klasikal dengan persentase nilai $86,7 \%$ sedangkan hanya 2 siswa belum mencapai ketuntasan individual dengan persentase nilai $13,33 \%$ sehingga mencapai ketuntasan klsikal (75\%). 


\section{DAFTAR PUSTAKA}

Nur Fajar "Penggunaan Media Audio Visual Dalam Meningkatkan Hasil Belajar Siswa Pada Materi Peninggalan Sejarah Di Kelas V Min Miruk Aceh Besar", Skripsi, Banda Aceh: Fakultas Tarbiyah dan Keguruan Uin Ar-Raniry, 2016

Oemar Hamalik, 2005, Kurikulum dan Pembelajaran, (Jakarta : Bumi Akhsara,)

Permendikbud No. 65 Tahun 2013 Tentang Standar Proses Pendidikan Dasar dan Menengah.

Robbins, Stephen P, 2007, Perilaku Organisasi Buku 1, (jakarta: Salemba Empat)

Rusman, 2013, Model Model Pembelajaran (Jakarta Rajawali Pers)

Rahmah johar, 2013,Dkk, Strategi Belajar Mengajar (Banda Aceh Unsyiah x)

Rusman,2003Model-model Pembelajaran:MengembangkanProfesionalisme

Guru. (Jakarta:Rajawalipers)

Sukmadinata, Nana Syaudih,2000 Pengembangan Kurikulum. (Bandung: Remaja Rosdakarya)

Sukardi, 2004 Metode Penelitian Kompetensi dan prakteknya, (Jakarta: Bumi Aksara)

Sri Anitah,2003Pembelajaran Terpadu: Paradigma Konstruktivistik Dalam Rangka Pengembangan Kecerdasan Ganda. Pidato Pengukuhan Guru Besar FKIP UNS. (Surakarta: Sebelas Maret University Press)

Suharsimi Arikunto, 2009 Peneltian Tindakan Kelas, (Jakarta :Bumi Aksara)

Suharsimi Arikunto, 2011 Penelitian Tindakan Kelas,(jakarta:PT Bumi Aksara)

Tim Pengembangan IImu Pendidikan FIP-UPI, 2011, IImu \& Aplikasi Pendidikan: Bagian 1- Ilmu Pendidikan Teoritis, (Jakarta: Grasindo)

Trianto.2009. Pengembangan Model Tematik. (Jakarta. Prestasi pustaka publisher) Trianto, 2011 Desain Pembelajaran Tematik (Jakarta:Kencana Pranada Media Guru) Tim pengembang MKDP,Kurikulum dan Pembelajaran, (Jakarta Utara: Raja Wali Press) 